\title{
DIETARY INTAKE AND SUN EXPOSURE RELATED TO VITAMIN D CONCENTRATION IN THALASSEMIA PATIENTS: A LITERATURE REVIEW
}

\author{
Yesi Herawati ${ }^{*}$, Gaga Irawan Nugraha ${ }^{2}$, Dida Akhmad Gurnida ${ }^{3}$ \\ ${ }^{1}$ Biomedical Sciences Master Program, Faculty of Medicine, Universitas Padjadjaran, Bandung, Indonesia \\ ${ }^{2}$ Biomedical Sciences Department, Faculty of Medicine, Universitas Padjadjaran, Bandung, Indonesia \\ ${ }^{3}$ Pediatrics Department, Faculty of Medicine, Universitas Padjadjaran, Bandung, Indonesia \\ *E-mail: yesiagustian1975@gmail.com
}

\begin{abstract}
Vitamin D has an important role in calcium homeostasis and bone minerals during rapid growth periods. Several studies have shown that deficiency of vitamin D occurs in thalassemia patient. The study used literature review to determine relation of dietary intake and sun exposure with vitamin D concentration in thalassemia patiens in 29 literatures. Those literatures were taken from books and articles published from 2010 to 2019 with the keywords "thalassemia", "dietary intake", "sun exposure" and "vitamin D" using database in Pubmed, Google Scholar and Medline. The results of 29 literatures showed that vitamin D deficiency is caused by reduced dietary intake and impaired vitamin D hydroxylation in the liver due to hemochromatosis resulting in high serum ferritin. Source of vitamin D comes from endogenous synthesis with sunlight exposure and little dietary source of vitamin D2 and vitamin D3. Another food intake can also affect serum vitamin D concentration, mainly fat and protein intake. Vitamin D is fat soluble vitamin, it can be stored in the fat for later metabolized in the liver. Protein is required to transport vitamin D to blood circulation, enzyme formation and vitamin D receptor (VDR). Thalassemia patients need to increase of macro and micronutrients requirement. Low $\mathrm{Hb}$ concentration causes fatigue, tired easily and decreased appetite. A lot of research on thalassemia children found that intake of energy and protein were lower than recommended and lack of sun exposure. These conditions will affect to vitamin D concentration. A comprehensive understanding in the relationship of dietary intake and sun exposure to vitamin D concentration in thalassemia patients is explained in this mini review. Maintaining normal vitamin $\mathrm{D}$ concentration through adequate dietary intake and sun exposure are very important to optimize growth in thalassemia patients
\end{abstract}

Keywords: dietary intake, sun exposure, thalassemia, vitamin D

\section{INTRODUCTION}

Thalassemia is a hematological disorder caused by deletions or mutations in one or more globin genes that are inherited in an autosomal recessive manner and results in impaired $\alpha$ or $\beta$ globin chain synthesis resulting in ineffective hemolysis and erythropoiesis (Tharwat et al., 2019; Galanello \& Origa 2010; Rachmilewitz \& Giardina, 2011). It has been estimated that about $1.5 \%$ of the global population (80 to 90 million people) are carriers of beta thalassemia, with about 60,000 symptomatic individuals born annually, the great majority in the developing world (Galanello \& Origa, 2010).

Vitamin D deficiency (VDD) in thalassemia major often occurs. Several countries in Asia report the occurrence of VDD in thalassemia major. A study in India in 2017 stated that only
$13 \%$ had normal vitamin $\mathrm{D}$ concentration, $41 \%$ had deficiency, and $46 \%$ had vitamin D insufficiency (Gombar et al., 2018), while in Upper Egypt, deficiency and insuficiency of vitamin D reached 91\% (Major et al., 2013). Vitamin D is formed through a complex metabolic process, derived from 7-dehydrocholesterol on the surface of human skin is changed into previtamin $D$ by ultraviolet $B$ (UVB) irradiation and then converted into cholecalciferol (vitamin D3) with slow thermal isomerization. Dietary sources of vitamin D (ergocalciferol and cholecalciferol) are hydroxylated in the liver and kidneys, liver enzymes will add hydroxyl groups $(\mathrm{OH})$ to cholecalciferol and ergocalciferol to produce 25 dihydroxyvitamin D3 (calcidiol). Calcidiol is synthesized in the kidneys and receives an additional hydroxyl group to 1,25 dihydroxyvitamin D3 (calcitriol), which is 
hydroxylated by the kidneys (Wang et al., 2017). Both hydroxylation causes metabolism of vitamin $D$ related to liver and kidney function (Iruzubieta et al., 2014; Kim, 2014). The number of vitamin D circulating in the body will decrease when hydroxylation is disrupted in the liver. (Gropper \& Smith, 2012).

Several studies have shown that the majority of thalassemia children experience inadequate food intake. Lack of vitamin D intake is the most common problem found. In a US cohort study of thalassemia major children with good nutrition, 97\% consumed inadequate vitamin D (Goldberg et al., 2018). In addition, energy and protein intake was also found to be lower than the recommended diet (Cortes-Penfield and Trautner 2017; Raimundo et al., 2011). Inadequate nutritional support will have an impact on not optimal growth and development and decreased immune function so that the quality of life of thalassemia children is low.

\section{METHODS}

This literature review was obtained through collecting, evaluating and analyzing related books and articles published in the last 10 years with the keywords "thalassemia", "dietary intake", and "vitamin D" using database on PubMed, google scholar and Medline that aims to find the relationship between dietary intake and sun exposure with vitamin $\mathrm{D}$ concentration in thalassemia patients. The inclusion criteria were cross sectional, cohort, intervention and literature studies. We excluded animal studies. Ethical clearance was obtained from ethics committee of Health Research Dr. Hasan Sadikin Hospital Bandung, Indonesia number LB.02.01/ X.6.5/312/2019.

\section{RESULTS AND DISCUSSIONS}

\section{Vitamin D}

Structurally, vitamin D is derived from a steroid which considered to be a seco-steroid because one of its broken four rings. Vitamin D contains three intact rings with a break between carbon 9 and 10 in the $\mathrm{B}$ ring. The two main types of vitamin D are vitamin D2 and vitamin

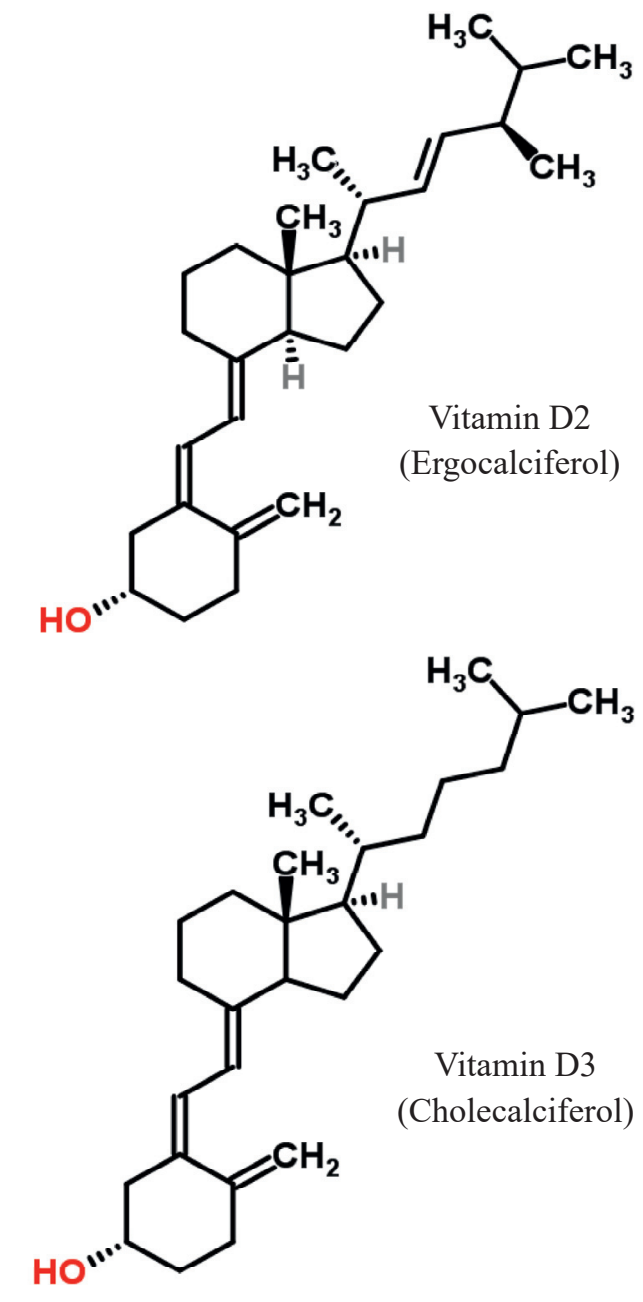

Figure 1. Chemical structure of vitamin D (Wacker \& Holiack, 2013).

D3 with different structure. The only structural difference between vitamin D2 and D3 is their side chains. The side chain for vitamin D2 contains a double bond among C22, C23, and a C24 methyl group. Active metabolites are synthesized in the kidneys and liver and transported through the blood to target organs and tissues, such as intestinal epithelium and bone (Gropper \& Smith 2012; Wacker \& Holiack 2013). Chemical structure of vitamin can be seen at Figure 1.

\section{Absorption, Transportation and Storage}

Figure 2 explains about absorption, transportation and storage of vitamin D. Vitamin D precursors are mainly obtained from 2 sources: endogenous synthesis and diet intake. In endogenous synthesis, cholecalciferol (vitamin D3) is synthesized from 7-dehydrocholesterol in the skin upon exposure to ultraviolet B. Vitamin 


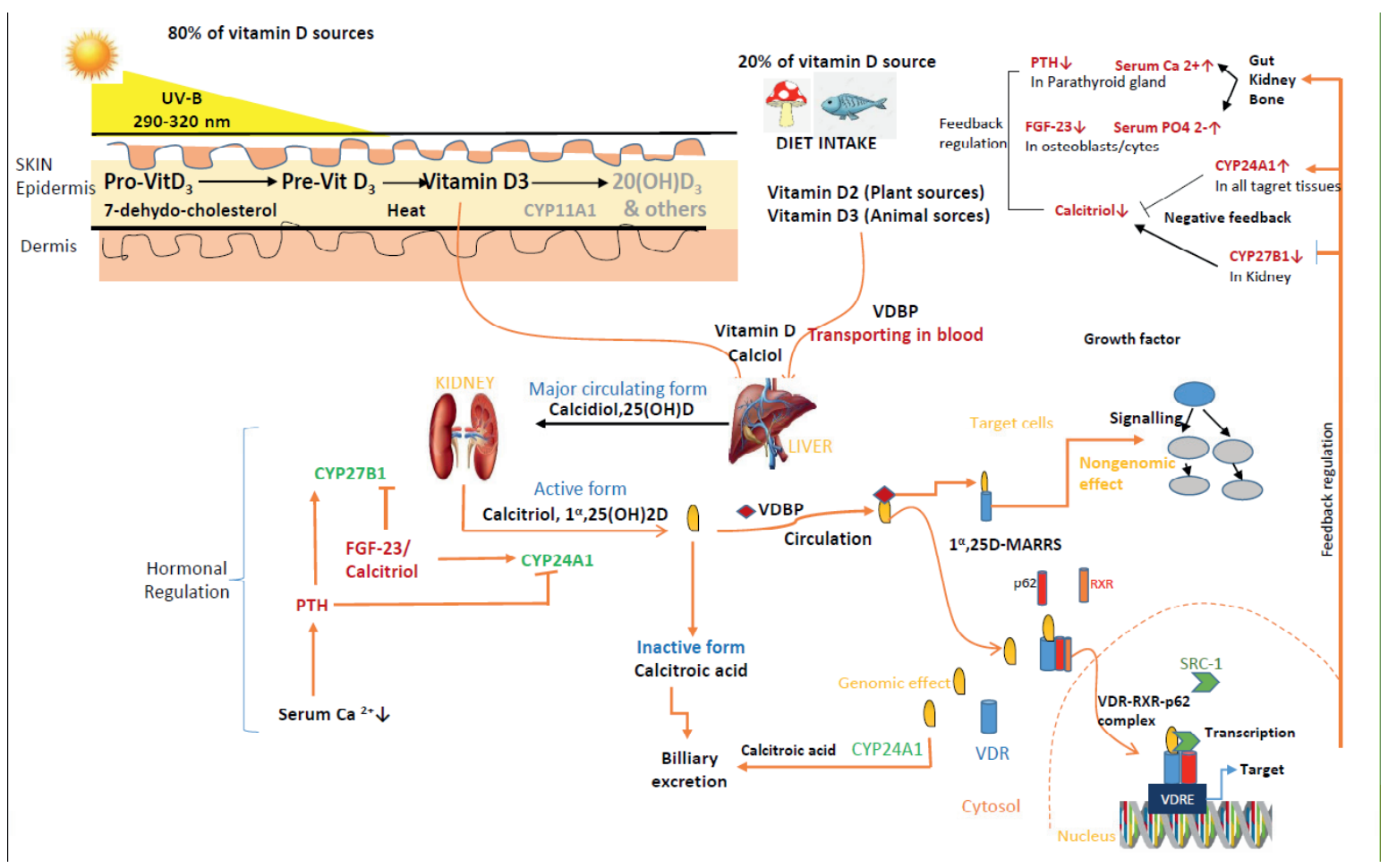

Figure 2. Vitamin D metabolism.

$\mathrm{D}$, which is derived from large portions of food, is obtained in the form of vitamin D3 (animal source) and/or as ergocalciferol (vitamin D2), the main precursor in plants. About $50 \%$ of vitamin D3 from the diet is absorbed from a micelle, in association with fat and aid of bile salts by passive diffusion into the intestinal cell. The largest amount of vitamin $\mathrm{D}$ is absorbed in the distal small intestine although the rate of absorption is most rapid in the duodenum. (Mahan, 2012; Chareles, 2015; Wilhelms et al., 2016; Herrmann et al., 2017; Aw et al., 2016).

Protein which is responsible for carrying various types of vitamin D is vitamin D3 binding protein (DBP). DBP has a high affinity and transporting $95-99 \%$ of the total $25(\mathrm{OH}) \mathrm{D} 3$, small portion is carried by albumin and lipoprotein through weak nonspecific bonds. (Mahan, 2012; Gropper \& Smith 2012). Vitamin D, from food and skin is metabolized to $25(\mathrm{OH}) \mathrm{D} 3$ in the liver by the enzyme 25 -hydroxylase and will be available as a reserve in circulation during 2-3 weeks (Rolfes et al., 2014; Herrmann et al., 2017).

In the blood, vitamin D binds to DBP forming a complex of vitamin D-DBP. The second metabolic process in the kidneys, $25(\mathrm{OH})$ $\mathrm{D}_{3}$ hydroxylates at $\mathrm{C}-1$, forming an active metabolite that is $1.25(\mathrm{OH}) 2 \mathrm{D} 3$ (calcitriol), and also at C-24 forming an inactive metabolite that is 24.25- dihydroxyvitamin D (24-hydroxycalcidol). Calcitriol is easily released from DBP and quickly bound the cell nucleus receptor, vitamin D receptor (VDR). In the kidney, 1.25(OH)2D3 stimulates tubular calcium reabsorption. In the small intestine, it stimulates calcium and phosphate absorption (Mahan, 2012; Rolfes et al., 2014; Gropper \& Smith 2012; Wilhelms et al. 2016, Herrmann et al. 2017; Sarmah \& Sharma 2014).

Production of extra renal tissue $1.25(\mathrm{OH})$ 2D3 works as an autocrine or paracrine signaling molecule locally and it's no contribute to circulating $1.25(\mathrm{OH}) 2 \mathrm{D} 3$ concentration (Herrmann et al., 2017).

In addition, VDR is found in almost all types of human cells, from brain to bone. Vitamin D directly or indirectly controls more than 3,000 genes related to calcium regulation and bone metabolism, modulation of innate immunity, cell growth and maturation, regulation of insulin and renin production, induction of apoptosis and inhibiting angiogenesis. Although many observational studies support a strong relationship vitamin D and effect of extra-skeletal, but there are not the exact proven low concentration of vitamin 
D causes various diseases (Sarmah \& Sharma, 2014).

Vitamin D homeostasis is controlled by the production of calcitriol. An increase of calcitriol causes a decrease in its own production directly or indirectly. Directly, calcitriol give negative feedback by 1-hydroxylase expression (Gropper, S. S., \& Smith, 2012). Calcitriol also decreases parathyroid hormone synthesis which increasing the transcription of 1-hydroxylase. The effect of calcitriol on parathyroid hormone is an indirect mechanism. When concentration of calcitriol increase, the expression of phosphaturic factor, fibroblast growth factor-23 (FGF-23) will be increase too. FGF-23 suppresses expression of 1-hydroxylase indirectly suppressing production of calcitriol. In addition, calcium and phosphate from food also affect the activity of 1-hydroxylase, which is an increase in calcium and phosphate decreases the activity of 1-hydroxylase. Calcitriol also decreases the synthesis of PTH. (Mahan K. 2012, Rolfes, S. R., Pinna, K., \& Whitney 2014, Gropper, S. S., \& Smith 2012).

In thalassemia patients, severe hemolysis requires repeated transfusions to maintain normal $\mathrm{Hb}$, and erythropoiesis causes increased iron absorption. The body loses 1-2 mg of iron per day, but blood transfusions contribute about $200 \mathrm{mg}$ of iron. Patients who receive 25 units of blood per year, will accumulate 5 grams of iron per year if chelation therapy is not given. This excess iron is toxic to all body cells and can cause irreversible damage that carries a high risk of morbidity and mortality if left untreated.

Progressive iron overload in thalassemia major patients can deposit in the liver parenchyma, heart, and other organs. These iron deposits can interfere with the hydroxylation of vitamin $\mathrm{D}$ in the liver and kidneys. The buildup of bilirubin under the skin which causes a yellowish discoloration of the skin can interfere with vitamin D synthesis. Several studies have shown an association between increased ferritin and decreased levels of vitamin D.

Ferritin is a universal intracellular protein that stores iron and releases it in a controlled fashion. The clinical consequences of iron overload in thalassemia patients are varied and reflect the key sites of iron storage. In the liver, the formation of collagen and portal fibrosis has been shown to occur after about two years of transfusion therapy. Thus, many studies show a significant increase in ferritin level in it. Patients affected by thalassemia major progressively develop iron overload, and a deficiency in liver hydroxylation of vitamin $\mathrm{D}$ (Gombar et al., 2018).

Several studies have reported a higher risk of vitamin $\mathrm{D}$ deficiency, decreased outdoor activities in thalassemic patients can also compromise cutaneous synthesis of vitamin D (Soliman, De Sanctis, \& Yassin, 2013).

\section{Functions and Mechanisms of Vitamin D}

Calcitriol has many functions and multiple mechanisms. The major mechanisms of calcitriol are genomics and non-genomics. In some cases, vitamin D works like a steroid hormone, acting through the activation of transduction signals that are bound to VDR cell membranes. Another case states that calcitriol functions to promote genomes by interacting with nuclear VDR to influence gene transcription. The binding calcitriol to VDR cell membranes in specialized tissues (such as intestine, parathyroid, bone, liver and pancreatic $\beta$-cells) triggers a sequencies of occasions through intracellular signaling pathways (called signal transduction) to generate relatively rapid changes in several bodily processes.

Many actions initiated with this binding include increased intestinal calcium absorption or transcellular calcium flux called transcaltachia (trans $=$ across, $c a l=$ calcium, and tachia $=$ rapidly) and gate calcium channels opened with a resulting increase in calcium uptake into osteoblasts and skeletal muscle cells. This cellular event is mediated by phosphorylation/dephosphorylation of a number of enzymes by the second messenger such as MAP kinase, protein kinase C, cAMP, tyrosine kinase, phospholipase C, diacylglycerol, inositol phosphate, and arachidonic acid. Rapid response associated with membrane steroid binding proteins (MARRS) can also play a role, interacting with G-proteins or other signal transduction mediators (Gropper, S. S., \& Smith, 2012).

Receptor of nuclear for vitamin D have been discovered in more than 30 organs, such as bones, intestine, kidney, lung, muscle, and skin. These receptors are part of the superfamily of receptors 


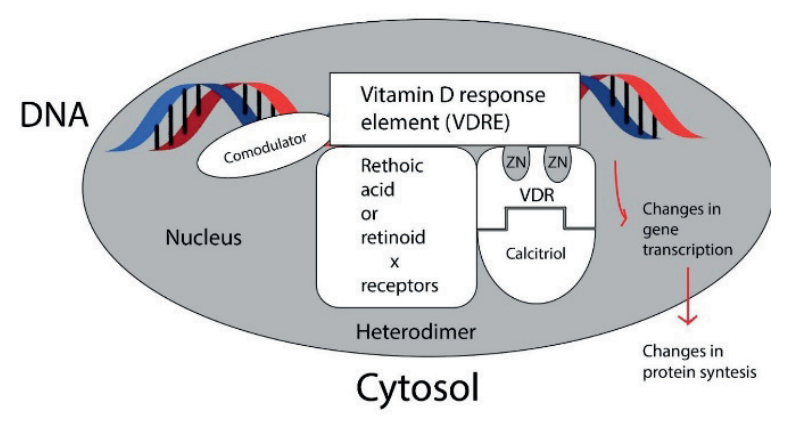

Figure 3. The role of vitamin $\mathrm{D}$ in gene expression

for retinoic acid, thyroid hormones and target tissue steroids. Calcitriol binds to nuclear VDR initiating conformational changes in the recently complex. Complex calcitriol-VDR is phosphorylated and then binds to retinoid $\mathrm{X}$ or retinoic acid receptors (RXR or RAR) to form heterodimeric complexes. The heterodimeric complex has zinc fingers interacting with certain vitamin $\mathrm{D}$ response elements (VDRE), discovered in the promoter region of specific target genes (Figure 3 ). When heterodimeric complexes are bound to VDRE, additional co-modulated proteins (coactivators or corepressors) interact with heterodimeric complexes to influence (increase or inhibit) the

transcription of protein-encoded genes.

The function of proteins is largely unknown, but they can help connect receptors with enzymes, such as RNA polymerase II, or another component like transcription factors. The comodulated proteins are SRC Family and NCoA-62. Proteins produced from the action of vitamin $\mathrm{D}$ in these genes are usually involved in calcium homeostasis, such as osteocalcin, 24 hydroxylase (CYP24), epithelial tracts of potent transient receptors of calcium type family member 6 (TRPV6), and calbindin (Gropper, S. S., \& Smith, 2012).

\section{Metabolism and Excretion of Vitamin D}

Calcitriol hydroxylation on carbon 24 produces metabolites $1.24 .25-(\mathrm{OH})_{3} \mathrm{D}_{3}$, then oxidized to 1.25-(OH)224-oxoD3. Subsequent reactions, calcitroic acid is produced by side chain cleavage (Figure 4). After hydroxylation and oxidation, other vitamin D metabolites are also formed. These metabolites can be conjugated and

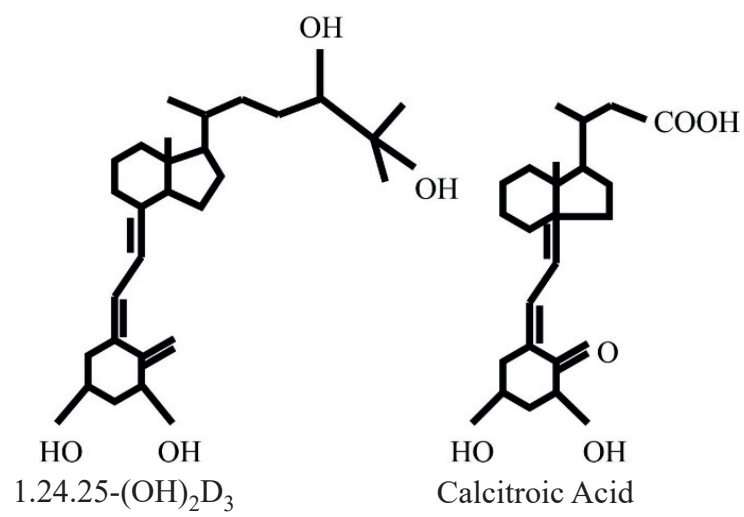

Figure 4. Some metabolites of vitamin D

excreted mainly in the bile. More than $70 \%$ of the vitamin D metabolites are excreted in the feces, with smaller amounts excreted in the urine.

\section{Measurement of Vitamin D}

Recent guidelines suggest the use of serum $25(\mathrm{OH}) \mathrm{D}_{3}$ concentration, which are measured by a reliable method for evaluating the status of vitamin $\mathrm{D}$ patients with have vitamin $\mathrm{D}$ deficiency risk. The best indicator of vitamin D status is serum $25(\mathrm{OH}) \mathrm{D}_{3}$ concentration, because of $25(\mathrm{OH}) \mathrm{D}_{3}$ concentration reflects the skin production and food source. Besides that, $25(\mathrm{OH}) \mathrm{D}_{3}$ has a long half-life in circulation which is 3-4 weeks. $1,25(\mathrm{OH})_{2} \mathrm{D}_{3}$ are not recommended for assessing vitamin $\mathrm{D}$ status because a half-life in the short circulation is 4-6 hours and its level in serum is very low, 1000 times lower than $25(\mathrm{OH}) \mathrm{D}_{3}$ concentration.

When deficiency of vitamin D occurs, parathyroid hormone secretion will increase as a compensatory response which will stimulate the kidneys increasing $1,25(\mathrm{OH})_{2} \mathrm{D}_{3}$ production so $25(\mathrm{OH}) \mathrm{D}_{3}$ concentration decrease while concentration $1,25(\mathrm{OH})_{2} \mathrm{D}_{3}$ is maintained at normal concentration and even increases (Wilhelms et al. 2016, Sarmah \& Sharma 2014, Wolf, 2018).

Although recent guidelines recommend measurement of $25(\mathrm{OH}) \mathrm{D}_{3}$ concentration to determinate vitamin $\mathrm{D}$ status there are exceptions where $25(\mathrm{OH}) \mathrm{D}_{3}$ concentration measurement cannot be used in kidney disease where the kidney ability to produce $1,25(\mathrm{OH})_{2} \mathrm{D}_{3}$ is low (Wilhelms et al., 2016). 


\section{Range value}

Expected $25(\mathrm{OH}) \mathrm{D}_{3}$ concentration are still unclear. Various organizations such as the Vitamin D Council, Endocrine Society and the Food and Nutrition Board Testing Laboratories have determined the range values for vitamin $\mathrm{D}$, but there is no consensus between these organizations.

At present, the range values determined by the Endocrine Society are the most widely used range values in medicine (Wolf, 2018), so most agree that VDD definition is if the $25(\mathrm{OH}) \mathrm{D}_{3}$ level $<20$ ng/ mL (Sarmah \& Sharma, 2014).

Determination of range values is still a problem today because several studies have found differences in concentration in various populations. Factors that cause differences in concentration between populations include melanin and obesity. Melanin provides protection against sunlight because it absorbs UVB photons. The dark skin people with more melanin pigment require longer sunlight exposure than light skin to produce the same vitamin $\mathrm{D} 3$ amount. Therefore, $25(\mathrm{OH}) \mathrm{D}_{3}$ concentration in people with dark skin are lower (Aw et al., 2016).

Obesity is also related to low $25(\mathrm{OH}) \mathrm{D}_{3}$ concentration, caused that vitamin $\mathrm{D}$ is sequestered in fat tissue (Sarmah \& Sharma, 2014).

\section{Vitamin D Requirement for Non-thalassemia and Thalassemia patients}

The current vitamin D recommendations are criticized for being inadequate. The requirement for vitamin D recommended in 1997 is unknown, by suggesting an adequate intake of $5 \mu \mathrm{g}$ or 200 IU per day for infants, children, adolescents, adults aged 19-50 years, including during pregnancy and breastfeeding (Mahan K. 2012, Rolfes, S. R., Pinna, K., \& Whitney 2014, Gropper, S. S., \& Smith 2012). More recent studies suggest at least
Table 2. Reference to Vitamin D intake

\begin{tabular}{lcc}
\hline \multicolumn{1}{c}{ Age group } & AI $(\boldsymbol{\mu g} / \mathbf{d a y})^{*}$ & UL $(\boldsymbol{\mu g} / \mathbf{d a y})^{* * *}$ \\
\hline $0-12$ months & $5(200 \mathrm{IU})$ & $25(10000 \mathrm{IU})$ \\
$1-50$ years & $5(200 \mathrm{IU})$ & $50(2000 \mathrm{IU})$ \\
$51-70$ years & $10(400 \mathrm{IU})$ & $50(2000 \mathrm{IU})$ \\
$>$ 70 years & $15(600 \mathrm{IU})$ & $50(2000 \mathrm{IU})$ \\
Pregnant and breastfeeding & $5(200 \mathrm{IU})$ & $50(2000 \mathrm{IU})$ \\
\hline
\end{tabular}

Sources: Institute of Medicine, Food and Nutrition Board (Mahan K. 2012, Rolfes, S. R., Pinna, K., \& Whitney 2014, Gropper, S. S., \& Smith 2012)

*AI: Adequate Intake

**UL: Tolerable upper intake level

Table 3. Recommended Dietary Allowances (RDA) of Vitamin D

\begin{tabular}{lclc}
\hline \multicolumn{1}{c}{ Age group } & $\begin{array}{c}\text { RDA* } \\
(\boldsymbol{\mu g})\end{array}$ & Age group & $\begin{array}{c}\text { RDA* } \\
(\boldsymbol{\mu g})\end{array}$ \\
\hline 0-11 months & 10 & Women: & \\
1 - 4 years & 15 & $10-64$ years & 15 \\
$5-9$ years & 15 & $65-80+$ years & 20 \\
Men: & & & \\
$10-64$ years & 15 & Pregnant & +0 \\
$65-80+$ years & 20 & Breastfeeding & +0 \\
\hline
\end{tabular}

*Recommended Dietary Allowances in 2019

$12.5 \mu \mathrm{g}$ (500 IU) per day, and $>25 \mu \mathrm{g}$ (1000 IU) per day may be needed by some people without sun exposure to maintain adequate concentration of vitamin $\mathrm{D}(\sim>80 \mathrm{nmol} / \mathrm{L}$ or $32 \mathrm{ng} / \mathrm{mL})$. This amount is considered to be obtained from sun exposure for about 5 to 15 minutes at around 10.00 to 15.00 in spring, summer, and autumn (Gropper, S. S., \& Smith, 2012).

The recommended nutritional adequacy concentration of vitamin $\mathrm{D}$ for various age groups and genders for Indonesia can be seen in Table 3.

Patients with thalassemia should have adequate vitamin $\mathrm{D}$ status to assure healthy bone accretion. Vitamin D status shall be assessed annually in all children and adults with thalassemia, can be seen in the following table.

Table 1. Level Vitamin D (Chareles S, 2015)

\begin{tabular}{cccc}
\hline Level & Vitamin D Council & Endocrine Society & Food and Nutrition Board \\
\hline Deficiency & $0-30 \mathrm{ng} / \mathrm{ml}^{*}$ & $0-20 \mathrm{ng} / \mathrm{ml}$ & $0-11 \mathrm{ng} / \mathrm{ml}$ \\
Insufficiency & $31-39 \mathrm{ng} / \mathrm{ml}$ & $21-29 \mathrm{ng} / \mathrm{ml}$ & $2-20 \mathrm{ng} / \mathrm{ml}$ \\
Sufficiency & $40-80 \mathrm{ng} / \mathrm{ml}$ & $30-100 \mathrm{ng} / \mathrm{ml}$ & $>20-150 \mathrm{ng} / \mathrm{ml}$ \\
Toxic & $>150 \mathrm{ng} / \mathrm{ml}$ & $>100 \mathrm{ng} / \mathrm{ml}$ & \\
\hline
\end{tabular}

*Description: Convert IU units to traditional units using the formula: $25(\mathrm{OH}) \mathrm{D} \mathrm{nmol} / \mathrm{l}=25(\mathrm{OH}) \mathrm{D}_{3} \mathrm{ng} / \mathrm{ml} \times 2.5$. 
Table 4. Recommendation for vitamin D assessment and therapy in patients with thalassemia (Soliman et al., 2013)

\begin{tabular}{|c|c|}
\hline Assessment of vitamin D & Frequency/dose \\
\hline $\begin{array}{l}\text { For thalassemic patients with } \\
25 \mathrm{OH} \text { D3 level }<20 \mathrm{ng} / \mathrm{ml}\end{array}$ & $\begin{array}{l}50000 \mathrm{IU} \text { of vitamin D2 } \\
\text { orally weekly for } 8 \text { weeks } \\
\text { or } 2000 \mathrm{IU} \text { of vitamin D3 } \\
\text { orally daily for } 8 \text { weeks or a } \\
\text { mega dose of } 10.000 \mathrm{IU} / \mathrm{kg} \\
\text { (max } 600.000 \mathrm{IU} \text { ) orally or } \\
\text { IM once. }\end{array}$ \\
\hline $\begin{array}{l}\text { For thalassemic patients with } \\
25 \mathrm{OHD} 3 \text { level }>20 \mathrm{ng} / \mathrm{ml} \\
\text { maintenance therapy can be } \\
\text { given especially in places } \\
\text { with poor sun exposure }\end{array}$ & $\begin{array}{l}800-1000 \mathrm{IU} \text { of vitamin } \mathrm{D} 2 \\
\text { orally daily or } 50.000 \mathrm{IU} \text { o } \\
\text { vitamin } \mathrm{D} 2 \text { orally per month } \\
\text { or a mega dose of vitamin } \\
\mathrm{D}(10.000 \mathrm{IU} / \mathrm{kg} \text {, maximum } \\
600,000 \mathrm{IU}) \text { orally or IM } \\
\text { every } 6 \text { months. }\end{array}$ \\
\hline
\end{tabular}

The other single randomized controlled trial demonstrated that supplementation with 400 to $1000 \mathrm{IU}$ of vitamin D per day for a period of 16 weeks increased serum $25(\mathrm{OH}) \mathrm{D}$ concentration from $28.7 \mathrm{nmol} / \mathrm{L}$ to $48.8 \mathrm{nmol} / \mathrm{L}$ while Serum Ferritin concentrations remained unchanged. A preventive health program where participants used higher doses (at the follow-up, median doses were 7000 IU per day) which achieved serum $25(\mathrm{OH}) \mathrm{D}$ concentrations to increase, on average, from 87.2 $\mathrm{nmol} / \mathrm{L}$ to $121.4 \mathrm{nmol} / \mathrm{L}$ (Munasinghe, Ekwaru, Mastroeni, \& Mastroeni, 2019).

\section{Source of Vitamin D}

Vitamin D is obtained by the body through body synthesis and dietary source. Residents of the tropics are at very low risk of developing deficiency of vitamin D. Infants and children are recommended to be in the sun for some time each day. Vitamin D deficiency is more likely to occur in countries that do not always get sunlight like 4 seasons countries (Gropper, S. S., \& Smith, 2012).

The major source of vitamin D in non-tropic areas is from food. Animal food is the main source of cholecalciferol, namely: egg yolks, liver, butter, and fish liver oil. Cow's milk and breast milk are not good sources of vitamin D. Vitamin D needs can be fulfilled through food fortification, especially milk, butter, food for babies with vitamin D2 (radiated ergosterol). Fish liver oil is often used as a vitamin D supplement for babies and children. Under normal circumstances vitamin D supplements are actually not needed. Vitamin D is relatively stable and is not damaged when heated or stored for a long time. The content of vitamin D in food can be seen in table 4 .

\section{Sun Exposure and Vitamin D Concentration}

Exposure of sunlight is the best source of vitamin D and there are no cases of vitamin D intoxication if excessive of sun exposure, because pre-vitamin D3 and vitamin D3 will absorb UVB

Table 5. Vitamin D content of various food ingredients ( $\mu \mathrm{g} / 100$ gram) (Wacker \& Holiack, 2013)

\begin{tabular}{|c|c|c|c|}
\hline Sources & $\mu \mathrm{g}$ & Sources & $\mu g$ \\
\hline Milk & $0,01-0,03$ & Fish liver oil & 210 \\
\hline Breast Milk & 0,04 & Margarinee from & $5,8-8,0$ \\
\hline Milk Flour & 0,21 & Broom, pork, lamb & Less \\
\hline Cream & $0,1-0,28$ & Poultry & Less \\
\hline Cheese & $0,03-0,5$ & Liver & $0,2-1,1$ \\
\hline Yoghurt & less $-0,04$ & Freshwater Fish & Less \\
\hline Egg & 1,75 & Fat Fish & less-25 \\
\hline Egg yolk & 4,94 & Shrimp and scallops & Less \\
\hline Butter & 0,76 & Fortified milk & 200-250 IU (D2 and D3) \\
\hline Livestock Salmon & $200-250 \mathrm{IU}$ & Cow's Milk Formula & 300 \\
\hline Canned Salmon & $300-600$ & Cereal & $40(\mathrm{D} 2)$ \\
\hline Canned Sardines & 300 & Cod liver oil & $400-1000$ \\
\hline Canned Mackerel & 250 & Shiitake Mushrooms & $1000-1600(\mathrm{D} 2)$ \\
\hline Canned Tuna & 230 & Button Mushrooms & 40 (D2) \\
\hline
\end{tabular}

$1 \mathrm{IU}$ vit $\mathrm{D}=0.025 \mu \mathrm{g}$ vit $\mathrm{D} 3$

$1 \mu \mathrm{g}$ vit $\mathrm{D} 3=40 \mathrm{IU}$ vit $\mathrm{D}$ 
solar radiation and undergo transformation into several photoproducts biologically inactive so it will not Vitamin D intoxication occurs.

The intensity of UVB sunlight is low at 07.00 am, increasing in the following hours until 11.00; after 11.00 this intensity is relatively stable and high until 14.00 and then decreases, and at 16.00 reaches the same intensity as at 07.00 .

Referring to Holick (2006) the required exposure time at an intensity of $1 \mathrm{MED} /$ hour is $1 / 4 \times 60$ minutes or equal to 15 minutes. If the exposure intensity is $2 \mathrm{MED} /$ hour, the length of service will be shorter. This intensity was only reached at 11.00-13.00. Exposure to sunlight on the face and arms for 25 minutes at 09.00 or 11.00 to 13.00 for 15 minutes has increased the concentration of vitamin D by 2700 IU each time of exposure. We recommend that to prevent VDD with exposure to sunlight 15-30 minutes for 2-3 times/week or 2 hours/week (Nimitphong \& Holick 2013; Gropper, S. S., \& Smith 2012)

Variations in vitamin level are influenced by seasons, with higher concentrations in summer, and lower in winter. The sun-rich country of Indonesia throughout the year is at $6^{\circ} \mathrm{N}$ (North Latitude) $11^{\circ} 08^{\prime} \mathrm{S}$ (South Latitude) and $95^{\circ}$ East-14 ${ }^{\circ}$ East. Individuals living near the equator get sun exposure without sun protection have concentrations of $25(\mathrm{OH}) \mathrm{D}$ above $30 \mathrm{ng} / \mathrm{mL}$. The use of chronic sunscreens can cause vitamin D deficiency. The use of sunscreens with SPF 8 decreases skin vitamin D production by $93 \%$ and will increase to $99 \%$ when using sunscreens with SPF 15 (Gropper, S. S. \& Smith 2012).

Thalassemia children tend to be exposed to more sun than adults. This is due to the majority of children playing outdoors during the day compared to adults who work indoors. One study stated that thalassemia children with ferritin $>1.000 \mathrm{ng} /$ dL, 30\% exposed to sunlight 1-2 hours/week and $32 \%$ exposed to sunlight $>2$ hours/week (Fadilah, Rahayuningsih, \& Setiabudi, 2017).

\section{Dietary Intake and Vitamin D Concentration}

Thalassemia patients are at risk of experiencing a lack of nutrient intake. Low $\mathrm{Hb}$ concentration cause fatigue, which causes decreased appetite and less food intake. In addition, eating habits that like to consume low-calorie foods, food intolerance (such as lactose), avoiding certain foods, especially foods high in iron, and side effects of chelation drugs (nausea, cramps, and zinc loss) can reduce the intake of thalassemia patients.

Ineffective erythropoiesis and rapid red cell turnover in thalassemia causes an increase in energy expenditure and other nutrients to maintain normal erythropoiesis. Thalassemia patients have increased energy expenditure and protein turnover (Meksawan et al, 2011). Vitamin D plays role in controlling RQ through glucose utilization and is therefore very positively related to basal and bone metabolism (Ogata et al., 2018).

Low vitamin D intake is possible due to low intake of vitamin D rich foods such as milk and vitamin D fortified foods, limited availability of foods containing vitamin D and lack of public purchasing power for vitamin $\mathrm{D}$ rich food sources because these vitamin $\mathrm{D}$ food sources are relatively expensive. A study conducted in Indonesia showed that the subject's vitamin D intake did not affect serum vitamin $\mathrm{D}$ concentration.

There are little dietary sources of cholecalciferol. The richest sources are oily fish like fish liver oils, salmon, mackerel, and tuna. Egg also contains a relatively large amount. Vitamin D can also be obtained from foods fortified with vitamin $\mathrm{D}$, including cereal products, bread products, milk, butter, cheese, margarine. Various multivitamins contain vitamin D3 plain (standard vitamin D) currently available on the market, as a nutritional supplement. In addition, there is now also available vitamin D3 which has been hydroxylated in the form of calcitriol and alfacalsidol. Calcitriol is an active vitamin D3 (already undergoing complete hydrosilation) that can work directly with the vitamin D receptors in the intestine so that it can increase calcium absorption in the intestine. Alfacalsidol is a synthetic active analogue of vitamin D which has been hydroxylated, which physiologically will take place in the kidneys only after the hydroxylation process in the liver.

Prevention of this deficiency at the age of 1950 years is done by taking vitamin $\mathrm{D}$ supplements at least $600 \mathrm{IU} /$ day so as to prevent bone disease and muscle function. However, vitamin D supplements $1500-2000 \mathrm{IU} /$ day is recommended to increase serum vitamin $\mathrm{D}$ above $30 \mathrm{ng} / \mathrm{mL}$ ( $\mathrm{Aw}$ et al., 2016). 
Macronutrients are predicted affect serum vitamin D concentration. Dietary source of vitamin $\mathrm{D}$ are fat and protein sources. Most food sources of protein and fat come from animals, while carbohydrate sources of food contain very little vitamin D. Based on the research of Nicolas et al, protein-rich foods such as fish, fortified milk and meat are the main sources of natural cholecalciferol (vitamin D3) which can suppress the activity of DHCR 7, a gene making enzyme that converts 7-dehydrocholesterol into cholesterol in human skin cells thereby affecting concentration of human vitamin D (Nicolas W. Cortes-Penfield, Barbara W. Trautner, 2017).

World Health Organization (WHO) recommends consuming fat as much as $15-30 \%$ of total calories. This amount meets the needs of essential fatty acids and helps the absorption of fat-soluble vitamins like vitamin D. Jungert et al's research in 2013 proved that fat intake is positively correlated with vitamin D intake and has an effect on vitamin D concentration (Jungert et al, 2014). Low or moderate fat intake makes vitamin $\mathrm{D}$ easier absorbed than high fat diet, no research can explain the reason. This is suspected that vitamin $\mathrm{D}$ becomes almost too soluble and forming clumps fat too large, making it difficult to pass through the intestinal lining. Vitamin D absorption is not influenced by the type of fatty acid (Raimundo et al., 2011). So, optimal nutrient intake is very important to prevent deficiency of vitamin D.

\section{CONCLUSION}

Vitamin D concentration in patients with thalassemia are not only influenced by dietary vitamin $\mathrm{D}$ intake and sun exposure, but also energy, protein and fat intake. Thalassemia patients should meet the needs of nutrients, especially macronutrients and quite exposed to sunlight at least 2 hours per week at a time of high UVB intensity to prevent vitamin $\mathrm{D}$ deficiency.

\section{REFERENCES}

Aw, T. C., Edin, F., Yap, C., \& Ascp, D. L. M. (2016). Vitamin D Measurements -- Facts and Fancies Vitamin D Measurements Facts and Fancies. Proceedings of Singapore
Health Care, 22(January), 227-234.https://doi. org/10.1177/201010581302200311

Chareles S, A. H. (2015). Vitamin D Deficiency, Metabolism and Routine Measurement of its Metabolites [25(OH)D2 and 25(OH)D3].Journal of Chromatography \& Separation Techniques, 06(04), 4-8. https://doi.org/10.4172/21577064.1000276

Fadilah, T. F., Rahayuningsih, S. E., \& Setiabudi, D. (2017). Hubungan Antara Kadar Feritin dan Kadar 25-Hidroksikolekalsiferol $\{25(\mathrm{OH}) \mathrm{D}\}$ Serum Pasien Thalassemia Mayor Anak. Sari Pediatri, 14(4), 246. https://doi.org/10.14238/ sp14.4.2012.246-50

Ferritin and Vitamin D Levels and Its Relation to Bone Diseases in Thalassemic Adults : A Hospital - Based Retrospective Cohort Study. Journal of Applied Hematology, 10(1), 15. https://doi.org/10.4103/joah.joah

Galanello, R., \& Origa, R. (2010). Beta-thalassemia. Orphanet J Rare Dis, 5, 1-15.

Gombar, S., Parihar, K., Choudhary, M., Gombar, S., Med, J. R., \& Feb, S. (2018). Comparative study of serum ferritin and vitamin $\mathrm{D}$ in thalassemia patients with healthy controls. Int J Res Med Sci, 6(2), 693-695.

Gropper, S. S., \& Smith, J. L. (2012). Advanced nutrition and human metabolism (sixth edit). Cengage Learning.

Herrmann, M., Farrell, C. L., Pusceddu, I., \& Fabregat-cabello, N. (2017). Assessment of vitamin D status - a changing landscape. Clin Chem Lab Med, 55(1), 3-26. https://doi. org/10.1515/cclm-2016-0264

Hollic, M. F. (2006). Vitamin D. In R. . Shils, M. E., Shike, M., Ross, A. C., Caballero, B., Cousins (Ed.), Modern nutrition in health and disease (tenth, pp. 376-393). Lippincott Williams \& Wilkins.

Iruzubieta, P., Terán, Á., Crespo, J., \& Fábrega,

E. (2014). Vitamin D deficiency in chronic liver disease. World Journal of Hepatology, 6(12), 901-915. https://doi.org/10.4254/wjh. v6.i12.901

Jungert, A., Spinneker, A., Nagel, A., \& NeuhaüserBerthold, M. (2014). Dietary intake and main food sources of vitamin D as a function of age, sex, vitamin D status, body composition, and income in an elderly German cohort. Food and Nutrition Research, 58, 1-8. https://doi. org/10.3402/fnr.v58.23632

K Goldberg, E., Neogi, S., Lal, A., Higa, A., \& Fung, E. (2018). Nutritional Deficiencies Are Common 
in Patients with Transfusion- Dependent Thalassemia and Associated with Iron Overload. Journal of Food and Nutrition Research, 6(10), 674-681. https://doi. org/10.12691/jfnr-6-10-9

Kim C, K. S. (2014). Vitamin D and chronic kidney disease. Korean J Intern Med, 29;4, 416-427.

Mahan K., S. S. E. (2012). Krause's Food, Nutrition and Diet Therapy (11th ed.). Philadelphia: WB Saunders Company.

Major, T., Fahim, F. M., Saad, K., Askar, E., Eldin, E. N., \& Thabet, A. F. (2013). Growth Parameters and Vitamin D status in. International Journal of Hematology-Oncology and Stem Cell Research, 7(4), 5-9.

Meksawan, K., Thongkijpreecha, P. , Kangsadalampai, O., \& Pongtanakul, B. (2011). Nutrition status in patients with thalassemia intermedia. FASEB Journal, 25. Retrieved from http://www.embase.com/ search/results? subaction=viewrecord\&from =export\&id=L 70753585\%5Cnhttp://www. fasebj.org/cgi/content/meeting_abstract/25/1_ MeetingAbstracts $/ 1 \mathrm{~b} 217$ ? sid $=4 \mathrm{ee} 095 \mathrm{f} 5-8 \mathrm{cc} 7-$ 49a1-8b00-b04cd5677bac\%5Cnhttp://sfx. library.uu.nl/utrecht?sid=EMBASE\&is

Munasinghe, L. L., Ekwaru, J. P., Mastroeni, S. S. S., \& Mastroeni, M. F. (2019). The Effect of Serum 25-Hydroxyvitamin D on Serum Ferritin Concentrations : A Longitudinal Study of. Nutrients, 11(692), 1-11. https://doi. org/10.3390/nu11030692

Nicolas W. Cortes-Penfield, Barbara W. Trautner, R. J. (2017). Vitamin D metabolism-related genetic variants, dietary protein intake and improvement of insulin resistance in a 2 year weight-loss trial: POUNDS Lost. HHS Public Access, 176(5), 139-148. https://doi. org/10.1016/j.physbeh.2017.03.040

Nimitphong, H., \& Holick, M. F. (2013). Vitamin D status and sun exposure in Southeast Asia,. Dermato-endocrinology, 5(1), 34-37.

Ogata, M., Iwasaki, N., Ide, R., Takizawa, M., Tanaka, M., Tetsuo, T., et al. (2018). Role of vitamin $\mathrm{D}$ in energy and bone metabolism in postmenopausal women with type 2 diabetes mellitus: A 6-month follow-up evaluation.
Journal of Diabetes Investigation, 9(1), 211222. https://doi.org/10.1111/jdi.12666

Rachmilewitz, E. A., \& Giardina, P. J. (2011). How I treat thalassemia. Blood, 118(13), 3479-3488. https://doi.org/10.1182/blood2010-08-300335

Raimundo, F. V., Faulhaber, G. A. M., Menegatti, P. K., Marques, L. D. S., \& Furlanetto, T. W. (2011). Effect of high- versus low-fat meal on serum 25-hydroxyvitamin D levels after a single oral dose of vitamin D: A singleblind, parallel, randomized trial. International Journal of Endocrinology, 2011. https://doi. org/10.1155/2011/809069

Rolfes, S. R., Pinna, K., \& Whitney, E. (2014). Understanding Nutrition (Eleventh ed). Thomson Learning, Inc.

Sarmah, D., \& Sharma, B. (2014). Interpreting the Laboratory Reports for Vit D Physiological Effects of the Two Forms of Vit D. The Journal of the Association of Physicians of India, 62(9), 797-800.

Soliman, A., De Sanctis, V., \& Yassin, M. (2013). Vitamin D status in thalassemia major: An update. Mediterranean Journal of Hematology and Infectious Diseases, 5(1). https://doi. org/10.4084/mjhid.2013.057

Tharwat, R. J., Balilah, S., Habib, H. M., Mahmoud, N. H., Beek, F. S., Almadani, F. K., et al. (2019).

Wacker, M., \& Holiack, M. F. (2013). Vitamin D-effects on skeletal and extraskeletal health and the need for supplementation. Nutrients, 5(1), 111-148. https://doi.org/10.3390/nu5010111

Wang, H., Chen, W., Li, D., Yin, X., Zhang, X., \& Olsen, N. (2017). Vitamin D and Chronic Diseases. Aging and Disease, 8(3), 346-353.

Wilhelms, M. A. J. K. W., Sanderson, C. J. L., Mc, U., \& Platteborze, L. T. C. P. L. (2016). Guiding Appropriate Laboratory Test Utilization. Military Medicine, 181(1), 10-11. https://doi. org/10.7205/MILMED-D-15-00253

Wolf, G. (2018). Nutritional Biochemistry of the Vitamins. The American Journal of Clinical Nutrition, 80(2), 532-533. https://doi. org/10.1093/ajen/80.2.532a. 